importance to manufacturers and timber users. This latter research is of first-class importance to the tropical sylviculturist, for such knowledge will assist him in the future management of tropical crops in which formerly only one or two species had any marketable timber value. Kiln-drying experiments are still being undertaken, especially in connexion with the hardwoods, where favourable results are being obtained. Satisfactory factors are coming to light in connexion with wood bonding and the weathering of plywood investigations. In this latter, weathering tests have been carried out both in Britain and in Nigeria over the past three years. The principal object of the tests was to assess the durability of the glues used in the manufacture of plywood. In the .entomology branch, studies of the common furniture beetle and the house longicorn beetle, the latter a serious pest on the Continent of Europe but in Great Britain chiefly confined to Surrey, have been given priority because of their importance.

\section{Similarity of Algal Proteins}

THE gross chemical composition of many algae has now been recorded. In a recent paper, W. Fowden (Ann. Bot., N.S., 18, 71, 258; 1954) describes how he has isolated representative protein fractions from species from four different systematic classes, namely, Chlorella, Anabaena, Navicula and Tribonema, and made quantitative determinations of their amino. acid compositions. This important investigation has shown that there is a close similarity in the proteins of the four species selected for study, and hence the tentative conclusion is reached that the protein complements of all algae are similar. It will be recalled that the contemporary accepted classification of the algae is based on the composition of their pigments and storage materials. The author points out that his analytical methods only provide an average amino-acid composition of the bulk protein of each species and can give no information regarding the nature and reaction of the individual proteins which may be present. He has also indicated that there is a general similarity between the bulk proteins of algae and those of the leaves and tubers of some flowering plants and of Nitrosomonas; but, as with the algae, these materials probably contain different individual proteins, these determining the characteristic metabolism of the species.

\section{Root Culture and Biochemical Genetics}

THE technique of excised root culture affords a means of investigating the hormonal control of plant growth and seems likely also to prove of value in biochemical-genetical studies of the tissues of higher plants. W. G. Boll (New Phytol., 53, 2, I77 ; 1954) has discussed the problems involved in the application of the technique of root culture to comparisons between strains and hybrids of the tomato. The growth of six clones of excised roots, each dërived from a different seed of one inbred plant of an inbred line of tomato, was studied through a series of passages. Both quantitative and qualitative differences were found between the clones. The implications of the results are discussed. Using a seven-day passage and a modified White's medium it was found that root apices, of the strains and hybrids of tomato used, only occasionally survived on subculture into a second passage. Experiments designed to overcome this difficulty are described. Reduction of the passage length, or control of $p H$ drift, increased the expectation of life of the apices on subculture; but conditions permitting continuous subculture of the radical apex were not realized. The implications of these results, and of the effects of the different media on the growth of excised tomato roots, are discussed.

\section{University of Birmingham}

Dr. C. A. Rogers, formerly reader in the Department of Pure Mathematics, University College, London, has been appointed to the Mason chair of pure mathematics in the University of Birmingham. The following appointments have been announced by the University: Dr. J. D. Lawson, lecturer in geology; Dr. J. N. Pratt, lecturer in physical metallurgy ; M. G. Cockeroft, lecturer in industrial metallurgy ; F. Benson, lecturer in engineering production; Dr. A. Kelly, Imperial Chemical Industries, Ltd., Fellow in industrial metallurgy. Dr. S. R. Carter, lecturer in chemistry in the University, has recently retired. The following have resigned their posts: Dr. C. S. Ball, lecturer in industrial metallurgy ; Dr. J. H. Cort, lecturer in physiology; Mrs. B. Eckstein, lecturer in geography; H. Grisbrook, lecturer in engineering production; Dr. H. Nuttall, lecturer in mechanical engineering; E. C. Park, research Fellow in physics; Dr. C. A. Ramm, lecturer in physics; G. K. Williamson, Imperial Chemical Industries, Ltd., research Fellow in physics; J. Y. Freeman, Department of Scientific and Industrial Research research assistant in physics; R. F. Coe, Department of Scientific and Industrial Research research Fellow in physics.

\section{Bishop Museum, Honolulu, Hawaii}

THE annual report of the Bishop Museum for 1953 recalls that the Bernice P. Bishop Museum was founded in 1889 with a sphere of interest described as "Polynesian and kindred antiquities, ethnography and natural history". The Museum made its reputation through its sponsorship of field research in the natural history and anthropology of the Pacific area and through publication of the results of such research. But those concerned with the Museum realized that their educational rolo lay in the diffusion of knowledge. Although the Bishop Museum had maintained exhibition halls, it had no policy in this direction, and one of the present major objectives is to transform the Museum into an effective instrument of education through informative and dramatic display techniques in the galleries.

\section{University of Sheffield}

THE following appointments have been made in the University of Sheffield: Dr. A. Roberts, senior lecturer in the Postgraduate School of Mining; P. B. N. Neal and D. M. Woo, lecturers in mechanical engineering; and P. H. Mann, lecturer in social studies. The following have resigned their posts in the University : Dr. H. E. Harding, reader in pathology, on appointment as director of pathology to the Salisbury Area Pathological Service; Dr. R. Shepherd, senior lecturer in the Postgraduate School of Mining, on appointment as a senior scientist with the National Coal Board; Dr. C. F. Davies, senior lecturer in medicine, on appointment as consultant physician to the United Sheffield Hospitals; B. R. Dudley, lecturer in applied mathematics; Miss C. M. Hamill, lecturer in pure mathematics; and F. G. West-Oram, lecturer in glass technology. Mr. P. Irwin Packington has given a cabin cruiser to the Department of Zoology for use in both coastal and inland waters. 